\title{
Good Corporate Governance And Intelectual Capital Determinant Earnings Response Coefficient
}

\author{
Nurul Aini ${ }^{1}$, Rudi Harianto ${ }^{2}$, Febrina Ramadhany ${ }^{3}$ \\ \{aininurul349@gmail.com ${ }^{1}$, rudiharianto_87@yahoo.co.id ${ }^{2}$ \} \\ Narotama University ${ }^{1,2}$
}

\begin{abstract}
The purpose of this study is to analyze the impact of good corporate governance and intellectual capital on the earnings response coefficient of banking firms listed in Indonesian Stock Exchange for 2014-2017 periods. This research is very useful in knowledge management in the banking company, especially for investors regarding the earnings response coefficient. The sample in this study was 32 companies, and total sample became 128 observations. The dependent variable in this study is the earnings response coefficient, while the independent variables are managerial ownership, audit committee, human capital, structural capital, and capital employed. The results show that managerial ownership, human capital, and structural capital no impact on earnings response coefficient, while audit committee has a negative impact on earnings response coefficient, capital employed has a positive impact on earnings response coefficient. The future research is consider stock prices to determine the earnings response coefficient.
\end{abstract}

Keywords: good corporate governance, human capital, structural capital, capital employed

\section{Introduction}

The development of the capital market is currently experiencing a significant increase. Issuers will compete in attracting investors to invest in their companies. However, investors have several considerations in investing because investors expect profits in their investments. Factors that are often used as considerations in investing are profits earned by companies that become investment objectives. Earnings information is information that can measure business success in achieving company goals. Published earnings information will cause a reaction or response that varies from investors. Therefore, published profits must be of high quality. The strong market reaction to earnings information will be reflected in the high earnings response coefficient (ERC), which shows that profit is of high quality. Earnings response coefficient (ERC) is a coefficient to measure unexpected accounting earnings in regression of abnormal stock returns in various other variables. With the comparison between the expected stock price and real stock price issued by the company, it is another word of the Earnings response coefficient (ERC) value in the high company describing investors will be interested in the company's earnings information that has been compared with companies whose value of earnings quality is smaller [1]. The low quality of earnings can lead to decision-making errors that have an impact on the reduction of company value. In the operation process, until the process of preparing financial statements requires good corporate governance (GCG) and supported by reliable resources. Good corporate governance (GCG) is corporate governance 
that explains the relationship between various participants in the company that determines the direction and performance of the company. If Good corporate governance (GCG) in the company runs effectively, the operating process and the process of preparing financial statements will produce high quality earnings. Reliable resources owned by the company can be described in intellectual capital (IC), which consists of human capital, structural capital, and capital employed. Intellectual capital (IC) is one approach that uses the measurement of intangible assets and valuations that are a concern and focus of the fields including, both sociology, information technology, management, and accounting. Affect earnings response coefficient (ERC) or earnings relationship with returns because it is proven by a significant 5\% [2]. This study uses good corporate governance (GCG) variable because reliable capital resources (intellectual capital) will not succeed without good corporate governance (GCG). Good corporate governance (GCG) is the company's initial guideline in determining the direction and performance of companies that must be supported by intellectual capital (IC) owned by the company. This study aims to analyze the effect of good corporate governance (GCG) and intellectual capital (IC) on earnings response coefficient (ERC) banking companies listed on the Stock Exchange with independent managerial ownership variables, audit committees, human capital, structural capital, capital employed.

\section{Literature Review}

\subsection{Agency Theory}

Agency theory explains agency is investor relations (principal) with contracts between managers (agents). The owner and agent is an interest conflict that occurs because of an agency that does not act with the interests of the principal, which will trigger the agency cost according to [3]

\subsection{Efficiency Market Theory}

Context of the context of efficient market theory, the existence of a market is a capital market and money market. What can be said to be efficient is a market that if no one is either an institutional investor or an individual investor, who will be able to get the risk by using an adjusted trading strategy, abnormal return [1]. Efficient markets can be reviewed from various angles of an efficient market and information efficient market that has been reviewed through the sophistication of a market so that it is based on information in making decisions until it is available in a decision with a market to be decisionally efficient market [4].

\subsection{Good Corporate Governance}

Good Corporate Governance (GCG) is a system that leads and can control the company [3]. The Indonesian Institute for Corporate Governance (IICG), which can define GCG is a structured process so that running a company can be applied, and has goals that enhance shareholder values. 


\subsection{Managerial Ownership}

Managerial ownership is a number of shares that have been owned by several management (managers) managerial share ownership can help interest interests among shareholders and managers. With the increasing proportion of shares held, managerial share ownership will improve the company's performance [5].

\subsection{Audit Committee}

Audit Committee is a committee that has members who are elected commissioners and can be held accountable for assisting management proposals that determine independent auditors. The number of members consisting of 3 to 5 or 7 members in an audit committee is not included in the management section [5].

\subsection{Intellectual Capital}

Intellectual Capital bring development to banking companies, which are useful for conducting assessments and measurements. Intellectual capital itself can also be called a business value. Intellectual capita is a business strategy that is based on and based on labor (labor-based business) that leads to knowledge-based business or which can be called a knowledge-based business, so companies that make the main characteristics can become companies that have competent and knowledgeable workforce [1].

\subsection{Human Capital}

Human Capital is a combination of which is attitude based on life in business, education, experience, genetic inheritance [6]. Human Capital is a reflection of the collective ability of the company to have the best solution based on the knowledge of someone owned by the existence of a company [7].

\subsection{Structural Capital}

Structural Capital covers the entire non-human storehouse of knowledge in the organization. That is one of Structural Capital, namely routines, strategies, process manuals, organizational charts, databases, and having material values greater than the value of the company [6]. Structural capital can be interpreted as a company that meets the process routinely for the company or an organizational capability and structured so that the goal can support the efforts of employees to produce an intellectual performance that optimizes overall business performance and overall [7].

\subsection{Capital Employed}

Capital Employed or Relational Capital is knowledge in a customer capital/relationship and marketing channels, one organization that develops through business [6]. 


\subsection{Earnings Response Coefficient}

Earnings Response Coefficient (ERC) is a measurement of the extent to which abnormal stock returns respond to the unpredictable component of earnings. Earnings Response Coefficient (ERC) itself is a measure of abnormal return to securities as a response that is found in the component of earnings (unexpected earnings) that have been reported by companies that issue securities [1]

\subsection{Research Hypothesis}

Managerial ownership can reduce the most important conflicts between agents and principals so that the company can improve managerial ownership. With the presence of managerial ownership, there will also be an increase in agency problems, which is the solution to the problems that the company will cause[5]. Managerial ownership has a significant influence on the direction of positive relations with profit quality [8].

$H_{1}$ : Managerial ownership has a positive effect on Earnings Response Coefficient

The audit committee will have the most important role in the company because the existence of an audit committee in the company will oversee external audits, internal control system, and financial statements in the company [9]. Research from (Irawati \& Sudirman, 2015) Audit committee has a positive and significant effect on earnings quality because the audit committee itself has an effective control function so that it can influence the performance of the company that produces quality earnings.

$\mathrm{H}_{2}$ : The audit committee has a positive effect on the Earnings Response Coefficient

Presence of human capital, there can be added value for the company in forming competencies and the effectiveness of teamwork, commitment, motivation. The added value will be donated to employees so that competency development, management culture changes, and transfer of knowledge from workers to companies [10]. Research from [2] intellectual capital (VAIC), which includes human capital has an influence on ERC or the relationship of earnings with returns because it is proven significantly.

$\mathrm{H}_{3}$ : Human Capital has a positive effect on the Earnings Response Coefficient

Structural capital, which includes storehouse of knowledge in organizations, which includes greater corporate value, better material value, and business, organitation charts, manual processes, databases, strategies [6]. Structural capital will require the procurement of large funds and a large maintenance burden because with the greater burden that has been used by the company to manage structural capital, then the value of efficiency is low. [7]. Research from [2] intellectual capital (VAIC), which includes structural capital has an influence on ERC or earnings relations with returns because it is proven significantly.

$H_{4}$ : Structural Capital has a negative effect on the Earnings Response Coefficient

Capital Employed is an association network or harmonious relationship with a partner company, whether it is qualified and has suppliers, and feels satisfied the company concerned and service members and loyal customers, whose relationship comes from companies with government and the community [11]. Research from [2] intellectual capital, which includes capital employed has an influence on ERC or earnings relations with returns because it proves to be significant.

$\mathrm{H}_{5}$ : Capital Employed has a significant positive effect on the Earnings Response Coefficient 


\section{Research Method}

The research method used in this study is quantitative research. This study uses sampling techniques using purposive sampling. The population used in this study is a banking sector company registered on the Stock Exchange in the period 2014-2017. The company used in this study uses a banking company listed on the Stock Exchange in 2014 - 2017 because banking companies are a country's financial system stability in managing finances. The target population of 32 companies can be taken as a sample. The total number of samples of 32 companies were listed on the Stock Exchange during the period 2014-2017 and those that met the requirements as samples, so the total number of samples obtained was 128 firm years.

\section{Discussion}

Table 1. Partial Test

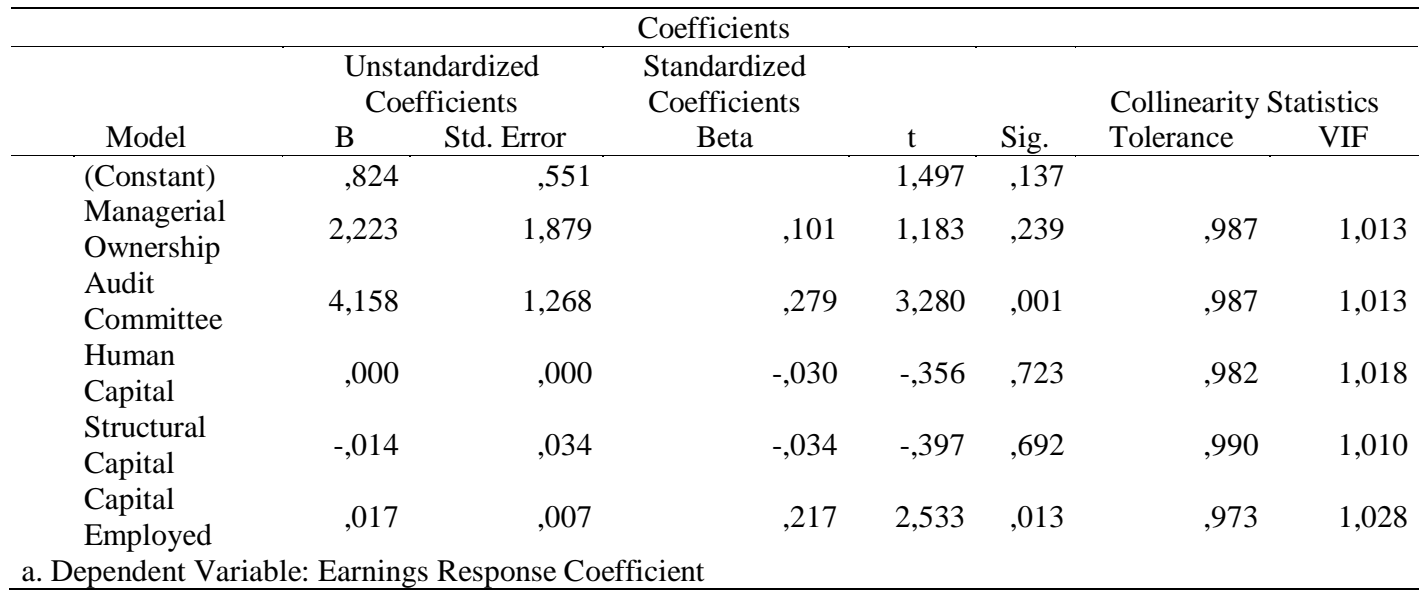

Managerial ownership has no effect on the Earnings Response Coefficient because this can be seen from the value of the $10 \%$ confidence level. This shows that the value of $\alpha$ is smaller than the t-sign value $(0.10<0.239)$. Thus testing shows H1 is rejected. Audit Committee has a negative influence on the Earnings Response Coefficient because this can be seen from the value of the confidence level of $1 \%$. This indicates that the value of $\alpha$ is greater than the $t$-sign value $(0.01>0.001)$. Thus the test shows $\mathrm{H} 2$ is rejected. Human Capital has no effect on the Earnings Response Coefficient because this shows that the value of $\alpha$ is smaller than the t-sign value $(0.10<0.723)$. Thus the test shows that H13 is rejected. Structural Capital has no effect on the Earnings Response Coefficient because this can be seen from the value of the confidence level of $10 \%$. This shows that the value of $\alpha$ is smaller than the $t$-sign value $(0.10<0.692)$. Thus the test shows that H4 is rejected. Capital Employed has a positive effect on the Earnings Response Coefficient because this can be seen from the value of the confidence level of $5 \%$. This indicates that the value of $\alpha$ is greater than the $t$-sign value $(0.01>0.013)$. Thus testing shows that H5 is accepted. 


\section{Conclusion}

Managerial Ownership does not affect the Earnings Response Coefficient. This is because managerial ownership is not able to influence the earnings response coefficient of a company. In this case, it shows that there is a conflict of interest within the company that can increase earnings response coefficients not proven. Audit Committee has a negative effect on the Earnings Response Coefficient. This is because the greater the audit committee will affect the proportion of audit committee members who will result in a decrease in the quality of earnings. Human Capital has no effect on the Earnings Response Coefficient. This is because high operational costs will cause company profits to fall so that investors will not respond with a decrease in profits in the company. Structural Capital has no effect on the Earnings Response Coefficient. This is because structure capital has not been able to improve the ability to generate corporate profits. The number of Structure Capital Efficiency (SCE) needed by the company has not been able to fulfill the company's routine process in producing optimal performance. Capital Employed has a positive effect on the Earnings Response Coefficient. This is because Capital Employed will produce a company profit, company value for managing human capital knowledge, skills, and expertise.

\section{References}

[1] M. Medy Nisrina and V. Herawaty, "Peran Intellectual Capital Disclosure Sebagai Pemodarsi Pengaruh Perataan Laba, Corporate Governance, Kesempatan Bertumbuh, Persistensi Laba Dan Leverage terhadap Keinformatifan Laba,” J. Tekun, vol. VII, no. 01, pp. 118-146, 2016.

[2] I. Saputra and S. Mulyani, "Pengaruh Intellectual Capital Terhadap ( ERC ) Earning Respons Coefficient Pada Perusahaan Perbankan Yang Terdaftar Di Bursa Efek Indonesia ( BEI ),” Din. Ekon. J. Ekon. dan Bisnis, vol. 9, no. 2, pp. 18-34, 2016.

[3] Hamdani, Good Corporate Governance: Tinjauan Etik Dalam Praktik Bisnis, 1st ed. Jakarta: Mitra Wacana Media, 2016.

[4] Y. S. J. Nasution, "Hypothesis Pasar Efisien / Efficient Market Hypothesis ( Pasal Modal menurut Teori Fama dan Pandangan Islam )," J. Perspekt. Ekon. Darussalam, vol. 1, no. 1, pp. 2543, 2015.

[5] Hermiyetti and E. Katlanis, "Analisis Pengaruh Kepemilikan Manajerial, Kepemilikan Institusional, Kepemilikan Asing, Dan Komite Audit Terhadap Kinerja Keuangan Perusahaan," J. Media Ris. Akunt., vol. 6, no. 2, pp. 25-43, 2012.

[6] I. Ulum. MD, "Intellectual Capital Performance Sektor Perbankan di Indonesia," J. Akunt. dan Keuang., vol. 10, no. 2, pp. 77-84, 2006.

[7] A. Pramanda and N. Husnah, "Pengaruh Intellectual Capital Terhadap Kualitas Laba dengan Corporate Governance sebagai Variabel Moderasi (Studi di Perusahaan Manufaktur Yang Terdaftar di Bursa Efek Indonesia Tahun 2011 dan 2012)," no. Ic, 2014.

[8] N. I. Puspitowati and A. A. Mulya, "Pengaruh Ukuran Komite Audit, Ukuran Dewan Komisaris, Kepemilikan Manajerial, dan Kepemilikan Institusional Terhadap Kualitas Laba," J. Akunt. dan Keuang., vol. 3, no. 1, pp. 219-239, 2014.

[9] Nadirsyah and F. N. Muharram, "Struktur Modal , Good Corporate," vol. 2, no. 2, pp. 184198, 2015.

[10] N. Supriatna, "Pengaruh Human Capital Terhadap Kinerja Auditor Pada Kap Yang Ada Di Bandung," J. Ris. Akunt. dan Keuang., vol. 2, no. 1, pp. 269-275, 2014.

[11] S. Arifah and D. H. Medyawati, "Analisis Pengaruh Elemen Intellectual Capital Terhadap Kinerja Keuangan Pada Industri Perbankan Yang Terdaftar Di Bursa Efek Indonesia," 2012. 